\title{
Peran Orang Tua dalam Pembentukan Kepribadian Anak di Era Digital
}

\author{
Nurlina ${ }^{1 *}$ \\ ${ }^{1}$ Institut Agama Islam Negeri (IAIN) Bone
}

\begin{tabular}{|c|c|}
\hline ARTICLE INFO & ABSTRACT \\
\hline $\begin{array}{l}\text { KEYWORDS } \\
\text { kepribadian; } \\
\text { anak; } \\
\text { orang tua; } \\
\text { digital; } \\
\text { personality; } \\
\text { child; } \\
\text { digital }\end{array}$ & $\begin{array}{l}\text { Pembentukan kepribadian anak berawal dari peran orang tua dalam keluarga, } \\
\text { sehingga keluarga merupakan tempat awal pendidikan dasar dan utama yang } \\
\text { cukup efektif dan efisien dalam upaya membekali kemampuan diri dengan } \\
\text { sebaik-baiknya pada anak sebagai generasi penerus, sehingga menjadi generasi } \\
\text { yang handal, terampil, tangguh serta berkarakter baik dan mulia di mata manusia } \\
\text { terlebih di mata Allah S.W.T. Agar anak bisa berkarakter baik dan mulia maka } \\
\text { ada beberapa pola asuh anak di era digital yang bisa dipraktikkan orangtua pada } \\
\text { anak agar hubungan tetap terjaga, yaitu tanggung jawab penuh, kedekatan, jelas } \\
\text { tujuan pengasuhan, selalu berbicara baik-baik, mengajarkan agama, } \\
\text { mempersiapkan anak masuk pubertas serta mempersiapkan mental anak di era } \\
\text { digital. Dalam perspektif Islam, pendidikan anak adalah proses mendidik, } \\
\text { mengasuh, dan melatih jasmani dan rohani mereka yang dilakukan orang tua } \\
\text { terhadap anak dengan berlandaskan nilai baik dan terpuji bersumber dari Al- } \\
\text { Qur'an dan Hadist. Karena anak merupakan amanah dari Allah Swt yang } \\
\text { diberikan pada orangtua. Anak adalah generasi penerus yang merupakan } \\
\text { tumpuan harapan serta kebanggaan keluarga dan diharapkan dapat membawa } \\
\text { kemajuan dimasa mendatang, sehingga keluarga merupakan lembaga } \\
\text { pendidikan pertama dan utama pada anak, maka peran orang tua mempersiapkan } \\
\text { diri dengan beragam pengetahuan untuk menemukan pola asuh yang tepat dalam } \\
\text { mendidik anak di era digital. }\end{array}$ \\
\hline
\end{tabular}

The formation of a child's personality begins with the role of parents in the family, so that the family is the initial place of primary and primary education that is quite effective and efficient in an effort to equip themselves with the best ability in children as the next generation, so that it becomes a reliable generation, skilled, tough and good and noble character in the human eye especially in the eyes of Allah S.W.T. In order for children to be good and noble in character, there are several parenting styles in the digital age that parents can practice with their children so that the relationship is maintained, that is full responsibility, proximity, clear goal of parenting, always talk carefully, teach religion, preparing children to enter puberty and preparing their children mentally in the digital age. In Islamic perspective, Children's education is an educational process, nurture, and train their physical and spiritual parents with children based on good values and praised by the Qur'an and Hadith. Because children are a mandate from Allah SWT given to parents. Children are the next generation that is the foundation of hope and pride of the family and is expected to bring progress in the future, so that the family is the first and foremost educational institution in children, then the role of parents prepare themselves with a variety of knowledge to find the right parenting in educating children in the digital era. 


\section{PENDAHULUAN}

Pembentukan kepribadian anak berawal dari peran orang tua dalam keluarga, karena kepribadian perilaku anak sangat mudah terpengaruh dari luar terutama di era digital saat ini. Sehingga keluarga merupakan awal dasar dalam pendidikan, dalam mendidik, mengasuh, serta mengenalkan segala hal yang positif pada anak agar dapat bersosialisasi dengan baik pada masyarakat sebagai mahluk sosial dengan memberikan kontribusi positif pada lingkungan. Karena keluarga merupakan lingkungan pendidikan dasar yang cukup efektif dan efisien dalam upaya mengantarkan generasi penerus dalam membekali kemampuan diri sang anak dengan sebaik-baiknya sehingga dapat menjadi generasi yang handal, terampil, tangguh serta berkarakter baik di mata manusia terlebih di mata Allah S.W.T., maka peran orangtua sangat penting dalam keluarga sebagai lembaga pendidikan utama informal.

Keluarga merupakan unit sosial terkecil dalam masyarakat, dan keluarga merupakan lingkungan pendidikan pertama dan utama dalam menanamkan norma dalam mengembangkan kebiasaan dan perilaku yang dianggap penting bagi kehidupan pribadi anak. Sebagai institusi pendidikan utama dalam keluarga tentu tidak bisa lepas dari berbagai tantangan besar membesarkan anak di zaman digital. Perkembangan dunia digital kadang membuat antara orangtua dan anak terjadi beda pandangan. Tak jarang berakhir dengan anak yang membangkang karena adanya perbedaan pandangan. Psikolog dan pendiri yayasan 'Kita Dan Buah Hati' Elly Risman membagi tujuh cara mengasuh anak di era digital yang bisa dipraktikkan agar hubungan antara orangtua dan anak tetap terjaga, yaitu:

a) Tanggung jawab penuh yaitu sama-sama bertanggungjawab atas jiwa, tubuh, pikiran, keimanan, kesejahteraan anak secara utuh. Masih banyak orangtua muda saat ini yang melepaskan anak-anaknya secara total di tangan orang ketiga, entah mertua atau pembantu. Tapi jika hal itu terpaksa dilakukan, maka perlu tetap pengontrolan sebagai orang tua dan tahu bagaimana sejarah dari orang yang anda rekrut untuk menjaga anak;

b) Kedekatan yakni perlu adanya kedekatan antara kedua orang tua ke anak. Kedekatan ini bukan hanya berarti melekat dari kulit ke kulit, melainkan jiwa ke jiwa. Artinya orang tua tak bisa hanya sering memeluk sang anak namun harus dekat secara emosional;

c) Harus jelas tujuan pengasuhan yaitu dari hasil riset yang saya lakukan untuk ibu usia 25-45 tahun, bekerja tak bekerja, ekonomi menengah ke atas dan menengah ke bawah. Mereka tidak punya tujuan pengasuhan. Mereka tidak tahu anak ini mau di bawa ke mana. Elly menyarankan agar orangtua mulai merumuskan tujuan pengasuhan sejak anak dilahirkan. Perlu membuat kesepakatan bersama suami, prioritas apa saja yang diberikan kepada anak dan bagaimana cara pendekatannya;

d) Berbicara baik-baik yakni orangtua harus berbicara baik-baik dengan anak. Tidak boleh membohongi, lupa membahas keunikan anak, dan juga perlu membaca bahasa tubuh, serta mau mendengar perasaan anak. Menyalahkan, memerintah, mencap, membandingkan, komunikasi seperti ini akan membuat anak merasa tak berharga, tak terbiasa memilih dan tak bisa mengambil keputusan;

e) Mengajarkan agama yaitu menjadi kewajiban orangtua untuk mengajarkan anakanaknya tentang agama. Pendidikan tentang agama perlu ditanamkan sedini mungkin. Dalam hal ini, mengajarkan agama tak hanya terbatas anak bisa membaca Al-Qur'an, bisa berpuasa atau pergi ke mesjid. Orangtua perlu menanamkan secara emosional agar anak menyukai aktivitas itu;

f) Persiapkan anak masuk pubertas yaitu kebanyakan orangtua malu dan menganggap tabu membicarakan masalah seks dengan anak dan cenderung menghindarinya. Menurut Elly, pembicaraan justru perlu dimulai sejak dini dengan bahasa yang mengikuti usianya; 
g) Persiapkan anak masuk era digital bukan berarti Anda harus memberikannya gadget sejak bayi. Namun mengajarkan anak jika penggunaan gadget ada waktunya dan memiliki batasan untuk itu, akses internet pun perlu dibatasi untuk mencegah anak melihat situs yang tidak diinginkan. Ajarkan mereka untuk menahan pandangan, menjaga kemaluan. Karena jika otak rusak, kemaluanmu tidak bisa dikendalikan. Jika kita tidak membicarakan, anak tidak tahu bagaimana akan bersikap. Kedepankan komunikasi sebagai pengganti gadget. Sebagai contoh, ajak anak bicara tiap kali pulang sekolah. Hal-hal di sekolah seperti tugas menumpuk, teman jahil atau guru menyebalkan sudah menjadi hal berat untuknya. Misalnya tanya perasaannya di hari itu, apa yang membuatnya bahagia dan apa yang membuatnya sedih. Dengan begitu, secara otomatis anak akan dengan mudah bercerita pada Anda sebagai orang tua tiap kali anak merasakan sesuatu.

\section{HASIL DAN PEMBAHASAN}

\subsection{Peran Orang Tua Pada Anak}

Anak adalah anugerah dan amanah dari Allah Swt yang harus di pertanggung-jawabkan oleh setiap orang tua dalam berbagai aspek kehidupan. Diantaranya bertanggung jawab dalam pendidikan, kesehatan, kasih sayang, perlindungan yang baik, dan berbagai aspek hidup lainnya.

Pendidikan anak perlu dilihat sebagai suatu proses yang berkelanjutan dan berkembang dengan perkembangan individu seorang anak yang mempelajari apa saja yang ada di lingkungannya. Dengan keahlian yang diperolehnya anak dapat mengaplikasikannya dalam konteks yang bermacam-macam dalam hidup keseharian anak ataupun sebagai persiapan untuk kehidupan anak dimasa yang akan datang.

Menurut perspektif Islam, pendidikan anak adalah proses mendidik, mengasuh, dan melatih jasmani dan rohani mereka yang dilakukan orang tua sebagai tanggung jawab terhadap anak yang berlandaskan nilai baik dan terpuji bersumber Al-Qur'an dan Hadist. Bahkan dalam Islam sistem pendidikan keluarga dipandang sebagai penentu masa depan anak. Sehingga dapat dikatakan bahwa surga atau neraka anak tergantung peran orang tua. Maksudnya adalah untuk melahirkan anak yang menjadi generasi insan yang rabbani yang beriman, bertaqwa, dan beramal shaleh adalah tanggung jawab orangtua maka peran orangtua sangat penting untuk kelangsungan kehidupan dunia akhirat sang anak.

Anak-anak di bentuk dan di didik sejak dari awal, Islam dan barat mempunyai perspektif yang sama dalam hal ini, yang membedakannya ialah Islam menekankan pembentukan dasar (ketauhidan) seorang anak bukan hanya kelakuan fisik dan intelektualnya saja, tetapi pemantapan akhlak perlu diterapkan seiring dengan penerapan keimanan di dalam ruh dan jiwa anak. Kalau informasi yang diterima oleh seorang anak hanya diatas pengetahuan tanpa adanya penanaman aqidah dan pemantapan akhlak akibatnya generasi yang dihasilkan mungkin bijaksana dan tinggi tahap perkembangan intelektualnya tetapi dari aspek-aspek yang lain (aqidah dan akhlaknya) kurang.

Sehingga peran orangtua dalam Islam harus bertanggung jawab dalam memberikan pendidikan sesuai dengan fitrahnya, yaitu keimanan kepada Allah Swt. Fitrah merupakan kerangka dasar operasional terhadap proses penciptaan manusia, didalamnya terkandung kekuatan potensial untuk tumbuh dan berkembang secara maksimal dan mengarahkannya untuk mencapai tujuan penciptaannya. Konsep dasar keimanan ini telah digambarkan dalam Al-Qur'an ketika Luqmanul Hakim memberikan pendidikan dasar terhadap anaknya.

Anak merupakan amanah dari Allah Swt yang diberikan kepada setiap orangtua, karena anak adalah buah hati serta tumpuan harapan serta kebanggaan keluarga. Anak adalah generasi 
mendatang yang mewarnai masa kini dan diharapkan dapat membawa kemajuan dimasa mendatang. Anak juga merupakan ujian bagi setiap orangtua sebagaimana disebutkan dalam Al-Qur'an surah al-Anfal ayat 28 yang berbunyi:

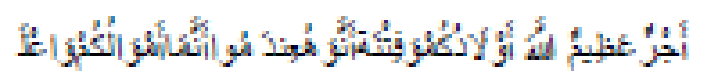

Artinya: "Dan ketahuilah bahwa hartamu dan anak-anakmu itu hanyalah sebagai cobaan dan sesungguhnya disisi Allahlah pahala yang besar." (QS.al-Anfal ayat 28).

Ayat diatas, menjelaskan salah satu ujian yang diberikan Allah kepada sebagai orang tua adalah anak-anak mereka. Itulah sebabnya setiap orangtua hendaklah benar-benar bertanggung jawab terhadap amanah yang diberikan Allah Swt sekaligus sebagai ujian yang harus dijalankan. Jika anak yang di didik mengikuti ajaran Islam maka orangtua akan memperoleh ganjaran pahala yang besar dari hasil ketaatan mereka.

Namun fakta yang ada masih banyak orangtua yang tidak bertanggung jawab terhadap anakanaknya karena masih banyak anak-anak yang tidak memperoleh hak sepenuhnya dari orangtua mereka seperti hak mendapatkan perawatan dengan penuh kasih sayang, hak memperoleh pendidikan yang baik dan benar, hak menerima nafkah yang halal dan baik, dan memberikan pengasuhan sepenuhnya kepada orang lain karena kesibukan dan sebagainya.

\subsection{Kedekatan Orang Tua Terhadap Anak}

Kedekatan anak dengan orangtua merupakan fondasi penting bagi tumbuh kembang anak. Kedekatan, kehangatan dan rasa cinta kasih orang tua dapat mencegah perilaku kenakalan dan depresi saat anak tumbuh dewasa. Kedekatan yang dijalin oleh orangtua kepada anak sejak dini juga akan berguna dalam pembentukan karakter anak. Kedekatan orangtua dan anak akan mempengaruhi kecerdasan anak. Seiring dengan pertumbuhan anak, ikatan emosional ini dapat berkembang melalui beberapa hal yang dapat di lakukan sehari-hari, yaitu:

a) Ketika bersama anak jangan hanya hadir secara fisik, namun hati dan pikirannya juga disentuh dengan kasih sayang. Banyak orangtua yang secara fisik hadir di sekitar anak, namun hatinya entah di mana. Meski orangtua menemani bermain, menyuapi, memandikan, namun anak tidak akan merasakan kedekatan kalau hal tersebut tidak dilakukan dengan cinta, di era digital saat ini banyak orangtua terlalu fokus pada gadget ketika bersama anak. Para ahli dan psikolog mengungkapkan bahwa anak yang diasuh oleh orang tua yang sering kali sibuk dengan dunia mereka sendiri, khususnya dunia gadget atau smartphone akan membuat anak mudah kehilangan fokus. Orang tua yang sering kali bermain smartphone saat bermain bersama anak, akan membuat anak kurang konsentrasi, kurang percaya diri dan kurang perhatian, karena itu ketika bersama anak fokuslah sama anak;

b) Belaian dan pelukan memberikan kedekatan yang diberikan oleh orang tua tidak pernah kadaluwarsa pengaruhnya sampai umur berapa pun. Anak yang tumbuh dengan penuh belaian dan pelukan akan mejadi anak yang lebih peka dan penuh kasih sayang terhadap sesama. Menurut Psikolog dan penulis buku The Miracle of Huge, Melly Puspita Sari bahwa memberikan pelukan pada anak minimal 8 kali sehari untuk memberikan energi sehingga anak bisa beraktivitas dan mengoptimalkan potensinya. ${ }^{2}$ Selain itu, Penelitian klinis dan psikologis menunjukkan bahwa pelukan antara orang tua dan anak dapat meningkatkan kecerdasan otak anak, merangsang produksi hormon dan oksitosin yang memberikan perasaan tenang dan bahagia serta membantu mengeluarkan zat berbahaya dari otak. Dalam bukunya 'The Hug Therapy', psikolog Kathleen Keating menyebutkan bahwa pelukan juga dapat meningkatkan kecerdasan otak dan IQ anak. ${ }^{3}$ 
c) Luangkan waktu karena momen berkualitas bersama anak tercipta dari aktivitas sederhana namun sering. Memang Waktu berkualitas (quality time) lebih efektif untuk membangun kedekatan dengan anak, akan tetapi tetap saja harus ada waktu yang dialokasikan khusus. Anak-anak membutuhkan keduanya, kuantitas dan kualitas waktu, kata Janie Lacy, konsultan kesehatan mental bersertifikat dari Orlando. Kebersamaan yang lebih sering dengan anak, menjadi momen untuk membangun kepercayaan, saling mempelajari bahasa cinta masing-masing antara orangtua dan anak, selain juga memahami sepenuhnya karakter anak. Momen berkualitas bersama anak tercipta dari aktivitas sederhana namun sering. Mulai saja dengan selalu berbicara dengan anak mengenai aktivitasnya seharian, lakukan percakapan sesering mungkin;

d) Pujian adalah motivator eksternal namun berikan pujian yang proporsional. Memberikan pujian bisa membangun kedekatan dengan anak karena anak merasa diapresiasi orangtuanya, selain itu pujian sangat dibutuhkan pada masa perkembangannya, tapi orangtua harus memberikan secara proporsional jangan berlebihan. Pujian yang pas akan menjadi pendorong bagi anak untuk mengulangi lagi melakukan sesuatu yang dianggap positif;

e) Memberikan kesempatan kepada anak, jangan terlalu mengontrolnya, kedekatan tidak sama dengan memanjakan anak. Contohnya di usia batita anak sedang belajar berjalan, meski bolak-balik jatuh, bahkan mungkin terbentur sesuatu, orangtua tetap harus memberikan kesempatan kepada batita mencobanya. Jangan karena alasan sayang dan takut jatuh maka tidak didorong untuk mencobanya, karena itu orangtua harus memberi kesempatan anaknya untuk melakukan sesuatu yang positif tanpa pengekangan yang berlebihan, jangan karena takut jatuh misalnya yang disebut kemanjaan berlebihan bisa membuat anak tidak mandiri. Penelitian Dr. Stafford yang dipublish dalam The Journal of Positive Psychology dan dikutip dari Mirror menemukan bahwa orangtua terlalu mengekang anak membuatnya tak bisa memiliki kontrol terhadap keadaan psikologisnya. Anak tidak bisa mengambil keputusan karena selalu dilarang orang tua dan tidak memiliki privasi akibat orang tua yang selalu ingin ikut campur. ${ }^{4}$

f) Belajar melakukan aktivitas harian akan membangun kedekatan dengan anak tidak berarti membuat anak hanya berdiam diri dilayani semua kebutuhannya. Anak tetap harus diberi kesempatan untuk melakukan aktivitas harian. Meski berusaha dekat, jangan menjadikannya sebagai raja kecil di rumah;

g) Ada kesempatan merasakan perpisahan, kalau sesekali berpisah anak bisa merasakan kedekatan dengan orangtuan. Anak akan merasa kangen dan membutuhkan orangtuanya. Latihan berpisah biasakan untuk mengucapkan selamat tinggal pada orang-orang yang meninggalkan kita agar anak melihat bahwa kita juga ditinggalkan oleh orang lain tetapi kita tidak merasa sedih, ijinkan anak untuk pergi bersama tante, kakek dan nenek, om tanpa orangtuanya.

\subsection{Harus Jelas Tujuan Pengasuhan}

Pengasuhan merupakan sebuah alat penyampaian pesan kepada anak mengenai nilai-nilai sehingga menjadi suatu variasi antar budaya dalam masyarakat. Pengasuhan atau disebut juga parenting adalah proses menumbuhkan dan mendidik anak dan kelahiran anak hingga memasuki usia dewasa. Sedangkan dalam buku Berns R.M dalam bukunya yang berjudul Child, 
Family, School, Community Social and Support dijelaskan bahwa Jerome Kagan seorang psikolog perkembangan Jerman (1975), menyebutkan bahwa pengasuhan merujuk pada serangkaian implementasi dari berbagai keputusan tentang sosialisasi pada anak apa yang harus dilakukan orang tua untuk menjadikan anak sebagai individu yang bertanggung jawab dan mampu memberikan kontribusi terhadap masyarakat, serta apa yang terbaik dilakukan orang tua dalam menghadapi beragam sifat anak ketika menangis, agresif, berbohong, marah, dll. ${ }^{5}$ Interaksi orang tua dan anak sangat dibutuhkan, karena anak belajar dari berbagai macam interaksi yang dilakukannya dengan orang tua. ${ }^{6}$

Agar tujuan pengasuhan orang tua terhadap anak jelas tentu beberapa strategi yang harus dilakukan oleh orangtua dalam melakukan pengasuhan, terutama dalam mendukung kompetensi seorang anak, diantaranya adalah:

a) Keterlibatan orangtua dalam menyediakan kesempatan untuk menumbuhkan kompetensi pada anak;

b) Memberikan kesempatan untuk eksplorasi bebas dan pemberian tugas;

c) Dipengaruhi oleh gaya pengasuhan orangtua;

d) Memberikan teladan perilaku;

e) Membentuk kelekatan emosi dan menciptakan keharmonisan keluarga;

f) Membimbing perilaku anak untuk mencapai tujuan hidupnya.

Berdasarkan buku Parenting karangan J.B. Brooks chapter 1 dijelaskan bahwa pengasuhan adalah sebuah proses, yang di dalamnya terdapat hubungan yang unik antara orang tua dan anak. Secara umum pengasuhan dapat dideskripsikan sebagai aksi dan interaksi orang tua dalam membangun perkembangan dan pertumbuhan anak. ${ }^{7}$ Seorang anak, terutama bayi dan balita sangat membutuhkan dukungan dalam pengasuhan dari orang tua dan juga dari lingkungan sekitarnya. Seorang anak akan mendapatkan pertumbuhan yang optimal jika terjalin hubungan dua arah dengan orang, benda, maupun simbol yang anak temukan pertama kali di lingkungan sekitarnya. Karena itu interaksi sangat penting untuk dilakukan secara berkesinambungan antara orang tua dan anak agar menjadi hubungan yang lebih kompleks dan akan menjadi stimulus dalam perkembangan seorang anak.

\subsection{Mengajarkan Agama Terhadap Anak}

Seorang Muslim, tentu tidak ada panduan yang lebih diutamakan dalam mengambil keputusan selain Al-Qur'an. Lantas, bagaimana cara kita menanamkan pendidikan akidah pada anak di zaman digital.

a) Dekatkan mereka dengan kisah-kisah atau cerita yang mengesakan Allah. Terkait hal ini para orangtua sebenarnya tidak perlu bingung atau kehabisan bahan dalam mengulas masalah cerita atau kisah. Karena, Al-Qur'an sendiri memiliki banyak kisah inspiratif yang semuanya menanamkan nilai ketauhidan. Akan tetapi, tergantung sejauh mana peran orangtua memahami kisah atau cerita yang ada di dalam Al-Qur'an. Karena apabila orangtua ternyata tidak memahami, maka meningkatkan intensitas atau frekuensi membaca Al-Qur'an sembari memahami maknanya menjadi kebutuhan yang tidak bisa ditunda. Kalaupun dengan cara membaca ternyata masih belum bisa. Orangtua bisa menyiasatinya dengan membeli buku-buku kisah dalam Al-Qur'an. Jadi, orangtua jangan pernah membelikan anak-anak buku cerita, novel atau kisah apapun yang tidak mengandung nilai akidah. Untuk itu, sejak dini anak-anak sudah harus memiliki kekuatan akidah sesuai dengan daya nalar dan psikologis mereka;

b) Ajak anak mengaktualisasikan akidah dalam kehidupan sehari-hari, karena apabila anak kita belum baligh, maka aktualisasi aqidah bisa dilakukan dengan mengajak anak 
mendirikan sholat misalnya. Sesekali kita kenalkan dengan masjid, majelis taklim, dan sebisa mungkin ajak mereka untuk senantiasa mendengar bacaan Al-Qur'an dari lisan kedua orangtuanya. Adapun kala anak kita sudah baligh maka orangtua harus tegas dalam masalah akidah. Jika anak sudah berusia 10 tahun dan tidak mendirikan sholat, maka memberi hukuman dengan memukul sekalipun, itu dibolehkan;

c) Peran orangtua mendorong anak untuk serius dalam menuntut ilmu dengan berguru pada orang yang di anggap bisa membantu membentuk frame berpikir islami pada anak. Orangtua tidak boleh merasa cukup dengan hanya menyekolahkan anak. Sebab akidah tidak bisa diwakilkan kepada sekolah atau universitas. Untuk itu, orangtua mesti memiliki kesungguhan luar biasa dalam hal ini. Misalnya ajak anak-anak kita untuk bersilaturrahim, berkunjung ke pesantren agar belajar, diskusi atau sharing masalah aqidah. Dorong mereka untuk mendatangi majelis-majelis ilmu yang diisi oleh ustadz, ulama atau pun figur publik muslim yang terbukti sangat baik dalam menguatkan akidah anak.

\subsection{Mengajarkan Agama Terhadap Anak}

Perkembangan seorang anak akan mengalami perubahan secara fisik maupun psikis dari masa kanak-kanak menuju masa dewasa. Di antara dua masa tersebut, ada masa peralihan, yang bisa di kenal dengan istilah remaja atau masa puber. Pubertas pasti akan dialami anak seiring dengan perkembangannya menjadi dewasa. Untuk menghadapi pubertas anak yang perlu dipersiapkam orang tua adalah dengan memberi bekal. Berikut ini hal-hal yang dapat dilakukan orang tua dalam mempersiapkan anaknya memasuki usia baligh seawal mungkin sejak usia pra baligh sekitar 7 tahun sampai 12 tahun:

a) Mengokohkan keyakinan (aqidah);

b) Menanamkan konsekuensi beriman pada Al Qur'an;

c) Hal-hal yang wajib atau sunah sudah harus dibiasakan;

d) Perbekalan tsaqofah Islam;

e) Mengajarkan dan membiasakan adab-adab (akhlak islami) terhadap orang tua;

f) Membentengi anak dari pengaruh tayangan media yang negatif;

g) Dalam hal pergaulan dengan lawan jenis, mulai di biasakan terpisah antara laki-laki dan perempuan;

h) Menjelang baligh mereka diajari tentang pengetahuan tanda-tanda baligh (menstruasi dan mimpi);

i) Membekali anak dengan keterampilan hidup;

j) Anak yg berusia 10 tahun ke atas mulai diajak berfikir untuk membaca persoalan umat;

k) Pemanfaatan teknologi yang tepat guna;

1) Melatih keberanian.

\subsection{Persiapkan Anak Masuk Era Digital}

Era digital memudahkan siapa saja mengakses informasi secara mudah, kapan saja dan di mana saja. Hal ini berlaku bagi siapa saja, termasuk anak-anak. Anak-anak era generasi millennial menjadi sangat cepat beradaptasi terhadap perkembangan teknologi informasi. Karenanya orangtua menghadapi banyak tantangan dalam membesarkan dan mengasuh anak-anak di era seperti sekarang. Karena saat ini, sudah terbuka akses informasi maupun komunikasi yang nyaris tanpa batas. Karena itu, sebaiknya anak-anak itu harus dibekali paling tidak tiga keterampilan mendasar dalam menghadapi kemajuan teknologi. 
a) Anak sebaiknya sudah ditanamkan keterampilan kognitif. Mereka memiliki kemampuan bukan saja merekam data atau fakta di sekelilingnya, tapi juga tahu bagaimana mengelola data, kemudian dipergunakan untuk memecahkan masalah yang belum ada formulanya;

b) Kemampuan interpersonal, yaitu anak harus punya kemampuan komunikasi yang baik agar bisa meyakinkan orang terhadap apa yang dia sampaikan. Kemampuan untuk mengamati dan mengerti maksud, motivasi dan perasaan orang lain. Peka pada ekpresi wajah, suara dan gerakan tubuh orang lain dan anak mampu memberikan respon secara efektif dalam berkomunikasi. Kemampuan ini juga mampu untuk masuk ke dalam diri orang lain, mengerti dunia orang lain, mengerti pandangan dan sikap orang lain;

c) Kemampuan internal personal, yaitu kemampuan dalam berkomunikasi dengan dirinya sendiri. Jadi anak perlu dibekali ketahanan mental, sehingga bisa mengelola gejala psikologis yang timbul dalam dirinya ketika berhadapan dengan dunia teknologi yang semakin hari semakin berkembang.

Karena era digital sudah merambah ke semua lapisan. Hal ini menuntut peran orang tua harus cerdas dalam menerapkan pola pengasuhan pada anak. Orang tualah yang menjadi madrasah pertama dan utama pada putra/putrinya sehingga dituntut peran aktif orang tua dalam mengasuh anak. Orang tua dituntut cerdas di tengah perkembangan zaman, jika hanya bekal pendidikan di sekolah saja maka tidak cukup untuk membekali anak-anak. Maka perlu peran penting orang tua atau keluarga dalam hal pengawasan baik di dalam keluarga, lingkungan juga sekolah supaya anak-anak memperoleh ilmu yang bermanfaat untuk masa depannya.

Rusmanto menjelaskan dari $100 \%$ pendidikan anak $60 \%$ berasal dari pendidikan keluarga. Dari $60 \%$ pendidikan anak tersebut maka tugas orang tua dalam mendidik anak sangat berpengaruh penting bagi anak, sedangkan $40 \%$ pendidikan anak didapatkan dari pendidikan sekolah dan lingkungan. 20\% didapatkan dari pendidikan sekolah dan $20 \%$ didapatkan dari pendidikan lingkungan. Maka Rusmanto mengimbuhkan bahwa keluarga menjadi lingkungan awal yang akan membawa pengaruh besar bagi anak. Sistem keluarga yang stabil akan memberikan pengaruh positif pada kecakapan hidup anak. Kokohnya sistem keluarga memberikan pengaruh yang baik bagi tumbuh kembang anak.

Hal itu juga ditegaskan oleh Dewan Pimpinan Cabang (DPC) Gabungan Organisasi Penyelenggara Taman Kanak-Kanak Indonesia (GOPTKI), Erny Widyawati Tasdi dengan adanya pola asuh anak yang baik dari orang tua, maka anak-anak tidak akan terpengaruh dengan lingkungan yang terkadang memberikan pengaruh negatif. Ia menambahkan mutu pendidikan terhadap anak yang diawali dari keluarga akan melahirkan generasi yang berkualitas dan berkarakter. Demi mendapatkan mutu pendidikan yang berkualitas, diperlukan dukungan dari seluruh pihak demi terciptanya generasi-genarasi penerus yang berkarakter.

Orang tua dituntut cerdas terutama di tengah perkembangan zaman dimana bekal pendidikan di sekolah saja tidak cukup untuk membekali pribadi anak-anak. Perlunya peran penting orang tua dan keluarga dalam hal pengawasan baik di dalam keluarga, lingkungan juga sekolah supaya anak-anak memperoleh ilmu yang bermanfaat untuk masa depannya. ${ }^{8}$

Jadi untuk menciptakan seorang pribadi anak yang multitasking, memiliki pengetahuan dan penguasaan IPTEK, bersifat terbuka termasuk dalam urusan pribadi mereka, cepat beradaptasi dengan lingkungan. Mendapatkan informasi demikian cepat membuat mereka menjadi generasi yang penuh dengan ide-ide visioner dan inovatif, cenderung bertanya dan memintra kritik serta saran untuk kemajuannya, diperlukan rewards terbaik bagi anak-anak dan dinilai sangat berarti bagi anak-anak. Tentu saja bagai dua sisi mata uang, kemajuan zaman yang serba cepat ini ada sisi positif dan negatifnya. Peran orang tua di era digital sangat berperan dalam upaya 
meminimalisir sisi negatif dan mengoptimalkan sisi positifnya. Sebuah tantangan berat bagi orang tua karena dituntut untuk sadar teknologi dan melek media di tengah tugas yang lainnya.

Meminimalisir dampak negatif dari teknologi digital adalah tugas dari para orang tua. Ada beberapa hal yang bisa di lakukan untuk menghadapinya. Secara garis besar terdapat tiga tugas orang tua yaitu, mengedukasi (nasehat), membatasi dan membentengi. Itu tiga hal pokok yang harus di ingat dan senantiasa dilakukan terhadap anak-anak. Pemahaman anak tentang efek negatif gadget tentulah belum banyak, jadi tugas sebagai orang tua untuk memberikan pemahaman fungsi dari teknologi yang memudahkan kehidupan manusia, manfaatnya dan efek negatif teknologi dalam hal ini gadget. Kemudian tujuan pemberian gadget kepada anak. Membatasi pemakaian internet memang wajib dilakukan baik itu waktu maupun situs-situs yang dituju. Sepakati bersama berapa jam anak bermain internet dalam sehari, apa saja yang boleh diakses, juga membatasinya dengan aplikasi yang bisa menyaring situs-situs konten dewasa, kekerasan dan games tidak bermanfaat serta film yang tidak mendidik.

Membentengi anak dengan agama memang sangat penting. Di jaman yang serba terbuka ini sudah tidak mungkin lagi mensterilkan anak dari internet. Berilah mereka iman, kekebalan untuk mampu menyeleksi sendiri apa yang baik untuk dirinya maupun yang tidak baik. Berilah pemahaman bahwa memang teknologi memudahkan tetapi agamalah yang akan menyelamatkan di dunia dan di akhirat. Jadikan pembelajaran keagamaan bukan sebatas doktrinasi dan hapalan, tapi sentuhlah emosinya hingga dia memahami, menyenangi bahkan merindukan ritual keagamaan, terlebih tentang kecintaan kepada Sang Pencipta, inilah peran utama bagi orangtua di zaman digital.

\section{SIMPULAN}

Globalisasi dengan segala dampaknya sudah tidak dapat dibendung lagi kedahsyatannya, dan oleh sebab itu orangtua mempunyai peran penting memberikan pendidikan yang terbaik untuk menyiapkan anak memasuki zaman yang persaingannya sangat ketat. Sehingga peran orangtua dalam membentuk karakter anak sangat penting bukan hanya untuk menjadi orang yang berilmu, tetapi juga yang berkarakter dan bermoral. Orangtua harus mengerti terhadap perkembangan dunia digital agar dapat mendampingi, mengawasi, mengontrol dunia digital anak-anak. Oleh karena itu, keluarga merupakan lembaga pendidikan yang pertama dan utama pada anak. ${ }^{9}$ Hal ini disebabkan, karena kedua orang tuanyalah yang pertama dikenal dan diterimanya pendidikan. Bimbingan, perhatian, dan kasih sayang yang terjalin antara kedua orang tua dengan anak-anaknya, merupakan basis yang ampuh bagi pertumbuhan dan perkembangan psikis serta nilai-nilai sosial dan religius pada diri anak.

Orang tua sebagai lingkungan pertama dan utama dimana anak berinteraksi sebagai lembaga pendidikan yang utama, artinya dimulai suatu proses pendidikan sehingga orang tua berperan sebagai pendidik bagi anak-anaknya. Lingkungan keluarga juga dikatakan lingkungan yang paling utama, karena sebagian besar kehidupan anak di dalam keluarga, sehingga pendidikan yang paling banyak diterima anak adalah dalam keluarga. Menurut Hasbullah, dalam tulisannya tentang dasar-dasar ilmu pendidikan, bahwa keluarga sebagai lembaga pendidikan memiliki beberapa fungsi yaitu fungsi dalam perkembangan kepribadian anak dan mendidik anak dirumah dan fungsi keluarga/orang tua dalam mendukung pendidikan di sekolah.

Fungsi keluarga dalam pembentukan kepribadian dan mendidik anak di rumah, yakni sebagai pengalaman pertama masa kanak-kanak, menjamin kehidupan emosional anak, menanamkan dasar pendidikan moral anak, memberikan dasar pendidikan sosial, meletakan dasar-dasar pendidikan agama, bertanggung jawab dalam memotivasi dan mendorong keberhasilan anak, memberikan kesempatan belajar dengan mengenalkan berbagai ilmu pengetahuan dan keterampilan yang berguna bagi kehidupan kelak sehingga anak mampu menjadi manusia 
dewasa yang mandiri, menjaga kesehatan anak sehingga dapat dengan nyaman menjalankan proses belajar yang utuh, dan memberikan kebahagiaan dunia dan akhirat dengan memberikan pendidikan agama sesuai ketentuan Allah Swt, sebagai tujuan akhir manusia. ${ }^{10}$

Untuk dapat menjalankan fungsi tersebut secara maksimal, orang tua harus memiliki kualitas diri yang memadai, sehingga anak-anak akan berkembang sesuai dengan harapan, orang tua harus memahami hakikat dan peran mereka dalam membesarkan anak, dengan membekali diri dengan ilmu tentang pola pengasuhan yang tepat, pengetahuan tentang pendidikan yang dijalani, dan ilmu tentang perkembangan anak, sehingga tidak salah dalam menerapkan suatu bentuk pola pendidikan terutama dalam pembentukan kepribadian anak yang sesuai dengan tujuan pendidikan yaitu mencerdasakan kehidupan bangsa dan mengembangkan manusia Indonesia seutuhnya, yaitu manusia yang beriman dan bertaqwa terhadap Tuhan Yang Maha Esa dan berbudi pekerti luhur, memiliki pengetahuan dan keterampilan, kesehatan jasmani dan rohani, kepribadian yang mantap dan mandiri serta rasa tanggung jawab kemasyarakatan dan kebangsaan.

Pendampingan orang tua dalam pendidikan anak diwujudkan dalam suatu cara-cara orang tua mendidik anak. Cara orang tua mendidik anak inilah yang disebut sebagai pola asuh. Setiap orang tua berusaha menggunakan cara yang paling baik menurut mereka dalam mendidik anak. Untuk mencari pola yang terbaik maka hendaklah orang tua mempersiapkan diri dengan beragam pengetahuan untuk menemukan pola asuh yang tepat dalam mendidik anak pada era digital.

Karena saat ini siapa pun orangnya, termasuk anak-anak sudah terbuka akses informasi maupun komunikasi yang nyaris tanpa batas. Jadi sebaiknya anak-anak harus dibekali paling tidak tiga keterampilan mendasar dalam menghadapi kemajuan teknologi yaitu:

a) Anak didik sebaiknya sudah ditanamkan keterampilan kognitif yaitu mereka memiliki kemampuan bukan saja merekam data atau fakta di sekelilingnya, tapi juga tahu bagaimana mengelola data itu, kemudian dipergunakan untuk memecahkan masalah yang belum ada formulanya;

b) Kemampuan interpersonal, yaitu anak harus punya kemampuan komunikasi yang baik agar bisa meyakinkan orang terhadap apa yang dia sampaikan. Kemampuan untuk mengamati dan mengerti maksud, motivasi dan perasaan orang lain. Peka pada ekpresi wajah, suara dan gerakan tubuh orang lain dan mampu memberikan respon secara efektif dalam berkomunikasi. Kemampuan ini juga mampu untuk masuk ke dalam diri orang lain, mengerti dunia orang lain, mengerti pandangan dan sikap orang lain;

c) Kemampuan internal personal, yaitu kemampuan dalam berkomunikasi dengan dirinya sendiri. Jadi anak perlu dibekali ketahanan mental, sehingga bisa mengelola gejala psikologis yang timbul dalam dirinya ketika berhadapan dengan dunia teknologi yang semakin hari semakin berkembang.

Peran orang tua di era digital memang lebih berat, karena perubahan zaman yang begitu cepat, dan dituntut untuk tidak tertinggal jauh dari anak-anak. Untuk memahami anak harus memahami kondisi zaman digital saat ini, karena anak-anak lahir dan terbentuk oleh kondisi zamannya. Seorang Ali Bin Abi Thalib pernah berkata "Didiklah Anak-anakmu agar siap menghadapi zamannya, karena mereka kelak akan hidup di zaman yang berbeda". 
Anak-anak zaman sekarang sebagai generasi digital mereka tumbuh bersama perangkat teknologi digital. Aktif berkomunikasi dan berinteraksi melalui media sosial dan menggunakannya dalam keseharian hidup mereka. Mereka cepat belajar berbagai aplikasi terbaru dengan berbagai fiturnya yang selalu up to date. Download lagu, film, main game, stalking akun, komen, chatting, upload aktifitas sehari-hari di media menjadi gaya hidup mereka. Tentu saja bagai dua sisi mata uang, kemajuan zaman yang serba cepat ada sisi positif dan negatifnya. Peran orang tua di era digital sangat berperan penting dalam upaya meminimalisir sisi negatif dan mengoptimalkan sisi positifnya. Sebuah tantangan berat bagi para orang tua karena dituntut untuk sadar teknologi dan melek media di tengah tugas yang lainnya.

\section{DAFTAR PUSTAKA}

Bertens K. 2011. Etika, Terjemahan A. Syauqi. Jakarta: Gramedia Pustaka Utama.

Hasbullah. Dasar Ilmu Pendidikan. 2005. Jakarta. Penerbit: PT Raja Grasindo.

https://cokiehti.wordpress.com/tag/majalah-al-waie/Akses16 Mei 2011.

https://dinkominfo.purbalinggakab.go.id/ pentingnya peran orang tua di era digital/ Akses 1 Agt 2017.

Ihsan, Faud. 2005. Dasar-dasar Pendidikan. Jakarta: PT Rineka Cipta.

J.B. Brooks. 2001. Parenting. Mayfield Publish Company.

Keating, D. P. 1990. At the threshold: the developing adolescence. Cambridge, MA: Harvard University Press.

R.M. Berns. 1997. Child, Family, School, Community Social and Support. Harcourt Brace Collage Publihers (Bab Ecology Parenting).

The Journal of Positive Psychology. Taylor \& Francis. J Posit Psychol. 2016 May 3; 11(3): 326-337. Published online 2015 Sep 15.

Sari, M. P. (2012). The Miracle of Hug. Jakarta: Gramedia Pustaka Utama. 